\title{
Antimicrobial Evaluation of Leaf and Stem Extract of Cordia macleodii
}

\author{
Deepkumar Joshi ${ }^{1, *}$, Rinku Patel ${ }^{2}$, Nupur Patel $^{2}$, Devendra Patel ${ }^{1}$ and Chintan Pandya ${ }^{2}$ \\ ${ }^{I}$ Chemistry Division, Sheth M. N. Science College, Patan; ${ }^{2}$ Chemistry Department, HVHP Institute of PG Studies and \\ Research, Kadi
}

\begin{abstract}
The leaf and stem of cordia macleodii plant were investigated for evaluating antibacterial and antifungal properties. Different extracts of leaf and stem viz. double distilled water, methanol, ethyl acetate ane n-hexane were collected and content was optimized for the maximum amount of extraction with varying time of 6 and $12 \mathrm{~h}$. The extracts were tested for their antimicrobial activities against gram-positive bacteria (B. sutilis), gram-negative bacteria $(E$. coli) and fungi (A. niger). The extracts were found to be more active against bacteria as compared to fungi. It was also observed that the antibacterial and antifungal potential of the water extracts were found to be excellent as $\mathbf{1 A}(38 \mathrm{~mm})$ and $\mathbf{1 B}(22$ $\mathrm{mm}$ ) compared to the other extracts.
\end{abstract}

Graphical Abstract:

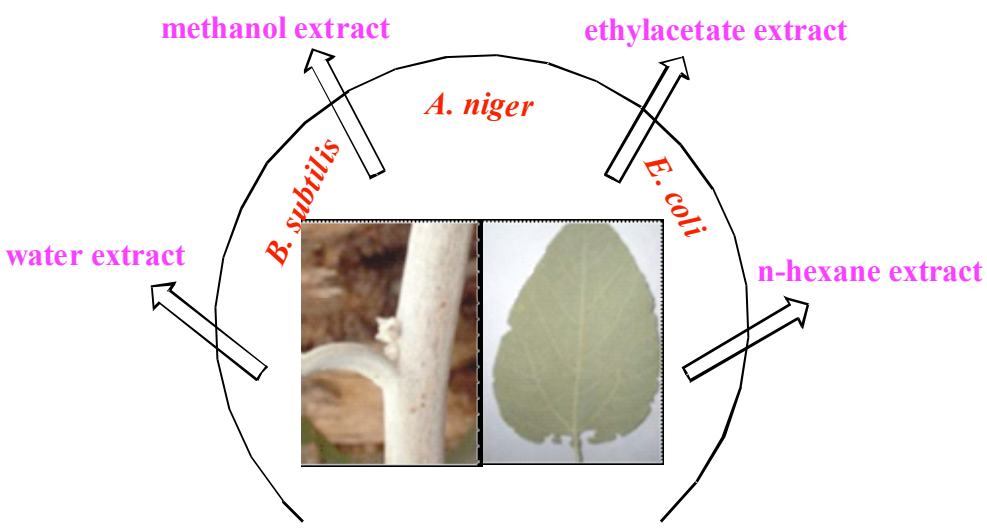

Antibacterial and antifungal extract from Cordia macleodii

Keywords: Antibacterial and antifungal evaluation, antimicrobial, Cordia macleodii, leaf extract, medicinal plants, stem extract.

\section{INTRODUCTION}

Medicinal plants are found to have great potential in healing the wound with minimal discomfort and pain to the patient [1]. Cordia macleodii belonging to Boraginaceae family and familiarly known as Dahiphalas, has green leaves and broad ovate. The leaves of cordia macleodii are found to possess antimicrobial property as reported by Acharya et al. [2]. The flavonoids content present in the leaf of the plant cordia macleodii is reported to exhibit antioxidant and hepatoprotective activities [3]. Also, the HPTLC profile conducted for analyzing the leaf content of the plant, shows the presence of alkaloids, glycosides, tannins at 254 and $366 \mathrm{~nm}$ [4]. The biological properties of the solvent extracts of leaf and other part of cordia macleodii have attracted us to study the antimicrobial properties against bacterial and fungal strains.

*Address correspondence to this author at the Chemistry Division, Sheth M. N. Science College, Patan; Tel: +91-9974147411;

E-mail: deepjoshi359@yahoo.co.in,

\section{EXPERIMENTAL}

\section{Materials and Methods}

Cordia macleodii plant was identified and collected for the analysis by the authentic authority from the Junagadh region of Gujarat state in India. Stem bark and leaves of the plant were cleaned to remove the dust and washed with water and dried. The dried parts were crushed to powder and stored in dry place away from moisture and direct heat. Solvents required for extraction were purchased from Merck Ltd. and SD fine chemicals.

\section{Extraction}

Stem and leaf powders around $12 \mathrm{gm}$ were added to 300 $\mathrm{ml}$ of solvents (double distilled water, methanol, ethyl acetate and n-hexane) and were exposed to hot extraction method for 6h using Soxhlet method of extraction [5] and $12 \mathrm{~h}$ by heating at $80^{\circ} \mathrm{C}$ with constant stirring [6]. The filtration process was carried out using whatman filter paper no. 1 , avoiding the loss of solvent. The left over residues were 
Table 1. Annotation of extracts collected from stem and leaf of Cordia macleodii.

\begin{tabular}{|c|c|c|c|c|}
\hline Time / Extract & Double Distilled Water & Methanol & Ethylacetate & n-hexane \\
\hline \hline $6 \mathrm{~h}$ & $1 \mathrm{~A}$ & $2 \mathrm{~A}$ & $3 \mathrm{~A}$ & $4 \mathrm{~A}$ \\
\hline $12 \mathrm{~h}$ & $1 \mathrm{~B}$ & $2 \mathrm{~B}$ & $3 \mathrm{~B}$ & $4 \mathrm{~B}$ \\
\hline
\end{tabular}

Table 2. Antibacterial and antifungal evaluation of different extracts from leaf of Cordial macleodii.

\begin{tabular}{|c|c|c|c|}
\hline Extract & $\begin{array}{c}\text { Gram-positive bacteria } \\
\text { B. subtilis }\end{array}$ & $\begin{array}{c}\text { Gram-negative bacteria } \\
\text { B. subtilis }\end{array}$ & $\begin{array}{c}\text { Fungi } \\
\text { A. niger }\end{array}$ \\
\hline \hline 1A & 22 & 0 & 0 \\
\hline 1B & 38 & 0 & 15 \\
\hline 2A & 6 & 0 & 0 \\
\hline 2B & 8 & 0 & 0 \\
\hline 3A & 7 & 0 & 5 \\
\hline 3B & 9 & 0 & 0 \\
\hline 4A & 7 & 0 & 0 \\
\hline 4B & 7 & 0 & - \\
\hline Std. & 25 & 24 & 25 \\
\hline Std. & - & - & \\
\hline
\end{tabular}

Values indicated in the table above are Zone of inhibition $(\mathrm{mm})$

Std. drug for antibacterial activity is ciprofloxacin and antifungal activity is fluconazole

dried and weigh to calculate the extractable matter in various solvents. The crude extract (filtrate) was collected and used for further biological evaluation.

The solvent extracts collected from stem and leaf were numbered in order to identify the samples during further analysis. The water extract collected after $6 \mathrm{~h}$ was titled $1 \mathrm{~A}$ and that after $12 \mathrm{~h}$ was named 1B. Similarly, the solvent extracts from methanol, ethylacetate and $n$-hexane were named 2, 3 and 4, respectively. Notation ' $A$ ' was used for $6 \mathrm{~h}$ and ' $\mathrm{B}$ ' for $12 \mathrm{~h}$ extract for each solvent extract as indicated in Table 1.

\section{Antibacterial and Antifungal Evaluation}

The antimicrobial tests were carried out using welldiffusion method with standard protocols. Each grampositive, gram-negative bacteria and fungi were employed for testing the antimicrobial potential of the stem and leaf extracts of the plant. B. subtilis (ATCC no. 6633-grampositive bacteria), E. coli (ATCC no. 25922-gram-negative bacteria) and $A$. niger (ATCC no. 1015-fungi) were used for antibacterial and antifungal testing of the compounds. Zone of inhibition (mm) was observed for each of the sample ranging from $1 \mathrm{~A}$ to $4 \mathrm{~B}$ and the results were reported in the Tables 2 and 3. Antibiotics like ciprofloxacin and fluconazole available in market were used as standard for antibacterial and antifungal analyses respectively.

\section{RESULTS AND DISCUSSION}

\section{Antimicrobial Activity}

The antimicrobial results showed in Tables $\mathbf{2}$ and $\mathbf{3}$ exhibited promising results against gram-positive bacteria $B$. subtilis and fungi $A$. niger, but showed poor results against gram-negative bacteria $E$. coli, when compared with the standards ciprofloxacin and fluconazole.

\section{Antibacterial and Antifungal Results of Leaf Extracts}

From Table 2, it was very clearly observed that none of the extracts was active against gram-negative bacteria $E$. coli. Water extracts $1 \mathrm{~A}(6 \mathrm{~h})$ and $1 \mathrm{~B}(12 \mathrm{~h})$ exhibited excellent results (22 and $38 \mathrm{~mm}$ ) against gram-positive bacteria $B$. subtilis. Leaf extract $1 \mathrm{~A}$ was found to be inactive against A. niger, but exhibited moderate zone of inhibition against the same fungal strain. As compared to the standards ciprofloxacin and fluconazole, other extracts exhibited low activity viz. $2 \mathrm{~A}, 2 \mathrm{~B}, 3 \mathrm{~A}, 3 \mathrm{~B}, 4 \mathrm{~A}$ and $4 \mathrm{~B}$ against the gram-positive bacterial strain $B$. subtilis. Methanol extract $2 \mathrm{~A}$ showed moderate results $(15 \mathrm{~mm})$ and ethylacetate extract $3 \mathrm{~B}$ exhibited poor activity ( $5 \mathrm{~mm}$ ) against $A$. niger

\section{Antibacterial and Antifungal Screening of Stem Extracts}

For testing antibacterial and antifungal potentials of the stem extracts as indicated in Table 3, same microbial strains $B$. subtilis, E. coli and A. niger were utilized. Very few extracts were found to show positive results against gramnegative bacteria E.coli viz. 3B (ethylacetate- $8 \mathrm{~mm}), 4 \mathrm{~A}$ (nhexane-2 $\mathrm{mm}$ ) and $4 \mathrm{~B}$ (n-hexane-5 mm). All the extracts showed poor to moderate results against B. subtilis $(3 \mathrm{~mm}$ to $19 \mathrm{~mm})$ as compared to the standard $(25 \mathrm{~mm})$. Among those, Water extract $2 \mathrm{~A}$ and $n$-hexane extract $4 \mathrm{~B}$, exhibited moderate results of $16 \mathrm{~mm}$ and $19 \mathrm{~mm}$ irrespectively. Stem extracts (1A to $4 \mathrm{~B}$ ) were found to possess low antifungal property when tested against $A$. niger. 
Table 3. Antibacterial and antifungal evaluation of different extracts from stem of Cordial macleodii.

\begin{tabular}{|c|c|c|c|}
\hline Extract & $\begin{array}{c}\text { Gram-positive bacteria } \\
\text { B. subtilis }\end{array}$ & $\begin{array}{c}\text { Gram-negative bacteria } \\
\text { B. subtilis }\end{array}$ & $\begin{array}{c}\text { Fungi } \\
\text { A. niger }\end{array}$ \\
\hline \hline 1A & 4 & 0 & 7 \\
\hline 1B & 16 & 0 & 3 \\
\hline 2A & 6 & 0 & 7 \\
\hline 2B & 13 & 0 & 2 \\
\hline 3A & 3 & 0 & 3 \\
\hline 3B & 7 & 8 & 6 \\
\hline 4A & 3 & 2 & 9 \\
\hline 4B & 19 & 5 & - \\
\hline Std. & 25 & 24 & 25 \\
\hline Std. & - & - & \\
\hline
\end{tabular}

Values indicated in the table above are Zone of inhibition $(\mathrm{mm})$

Std. drug for antibacterial activity is ciprofloxacin and antifungal activity is fluconazole

\section{CONCLUSION}

The antimicrobial results very well indicated that the water (1B) and n-hexane (4B) extracts collected after $12 \mathrm{hrs}$ were found to show excellent results, also, the antibacterial potential of water extract of leaf (1B) of Cordia macleodii was found to be more than the standard drug ciprofloxacin. Overall, the extracts were active against gram-positive bacteria $B$. subtilis and fungi $A$. niger. It was also observed that the extracts collected after $12 \mathrm{hrs}$ exhibited comparatively more antibacterial and antifungal values than the extracts collected after $6 \mathrm{~h}$. Further optimization in the extraction method and identification of the chemical constituent in the leaf and stem extracts can help in providing a newer antimicrobial agent to the society.

\section{CONFLICT OF INTEREST}

The authors confirm that this article content has no conflict of interest.

\section{ACKNOWLEDGEMENTS}

Authors are thankful to Kadi Sarva Vishwvidyalaya, Gandhinagar and Sarva Vidyalaya Kelavani Mandal, Kadi for providing infrastructural facilities to the researchers to carry out the work. Authors are thankful to Prof. B. A. Golakiya for his kind help in literature survey and identification and collection of Cordia macleodii plant.

\section{REFERENCES}

[1] MacKay DJ, Miller AL. Nutritional support for wound healing. Alternat Med Rev 2003; 8(4): 359-77.

[2] Bhide B, Ashok BK, Acharya RN, Ravishankar B. Anti-microbial and wound healing activities of Cordia macleodii Hook. f \& Thoms. leaves. Ind J Nat Prod Resour 2011; 1: 198-203.

[3] Qureshi NN, Kuchekar BS, Logade NA, Haleem MA. Antioxidant and hepatoprotective activity of Cordia macleodii leaves. Saud Pharm J 2009; 17(4): 299-302.

[4] Bhide B, Acharya RN, Naria P, Pillai APG, Shukla VJ. Pharmacognostic Evaluation of Cordia macleodii Hook. Stem Bark. Pharmacog J 2011; 3(26): 49-53.

[5] Wang L, Weller CL. Recent advances in extraction of nutraceuticals from plants. Trend Food Sci Technol 2006; 17(6): 300-12.

[6] Akroum S, Satta D, Lalaoui K. Antimicrobial, antioxidant, cytotoxic activities and phytochemical screening of some Algerian plants. Eur J Sci Res 2009; 31(2): 289-95.

(C) Joshi et al.; Licensee Bentham Open.

This is an open access article licensed under the terms of the Creative Commons Attribution Non-Commercial License (http://creativecommons.org/licenses/by-nc/3.0/) which permits unrestricted, non-commercial use, distribution and reproduction in any medium, provided the work is properly cited. 